\title{
CLASSIFICATION OF SOME NEW MAIZE HYBRIDS ACCORDING TO EARLINESS AND PHYSIOLOGICAL MATURITY RELATED TRAITS UNDER LOW AND HIGH NITROGEN FERTILIZATION CONDITIONS \\ Ibraheem, F. ${ }^{1}$ and M. A. Abdel-Moneam ${ }^{2}$ \\ 1, Botany Dept., Fac. of Sci., Mansoura Univ. Egypt, Email: farag100@mans.edu.eg
}

2, Agronomy Dept., Fac. of Agric., Mansoura Univ. Egypt, Email: maaelmoneam@mans.edu.eg

\begin{abstract}
Production of new maize hybrids with desirable package of earliness and physiological maturity related traits without compromising grains yield is critical for various agricultural systems worldwide. This investigation were carried out during 2012 season to evaluate the impact of the different genetic makeup of a set of thirteen new hybrids, developed by the authors during 2011 season, on flowering related traits such as anthesis, silking, anthesis-silking intervals (ASI), and the efficiency of light absorption of plant cover as well as physiological maturity related traits such as grains filling period, and grains filling rate. The impact of these traits on ear yield under both $\mathrm{N}$ stress and $\mathrm{N}$ sufficient conditions was also investigated. The results revealed that the tested hybrids exhibited significant differences in all tested flowering related traits. Based on the phenotype of their earliness traits (days from sowing to $50 \%$ flowering) and the general mean value of these traits (60.24 days for flowering), the tested hybrids were relatively categorized into early flowering early flowering (with number of days from $\leq 50$ to 55 days, e.g. B73X PHG47, B73X HP301, B73X PH207, B73X $\mathrm{PHj40,}$ B73X NC358, B73X Mo17), intermediate flowering (hybrids with number of days from 55 to 65 days, e.g. B73X CML103, B73X Tzi8, B73X B97, B73X Rg5, B73X Inb209, B73X Sids63), and late flowering (with number of days from 65 to $\geq 70$ days, e.g. B73X Inb.204, and the check crosses SC3084, SC173, SC168, SC167, SC10) hybrids. The results also revealed significant differences among the tested hybrids in grains filling period, grains filling rate, and physiological maturity under both $\mathrm{N}$ stress and $\mathrm{N}$ sufficient conditions. The magnitude of grains filling rate ranged from $1.4 \mathrm{~g} / \mathrm{day}$ to $6.8 \mathrm{~g} /$ day. Based on the values of individual and general mean grains filling rates, the tested hybrids were classified into low rate grains fillers $(\leq 1.4$ to $3.5 \mathrm{~g} / \mathrm{day}$, e.g. B73X HP301, B73X PHj40 and B73X PH207), intermediate rate grains fillers (3.5 to $4.5 \mathrm{~g} /$ day, e.g. B73X Phg47, B73X B97, B73X Mo17, B73X Inb209, B73X Sids63, B73X Rg5, B73X Inb.204, SC3084, SC168, SC167, SC173, SC10) and rapid rate grains fillers (4.5 to $\geq 6$ gram/day, e.g. B73X CML103, B73X TZI8 and B73X NC358) under $\mathrm{N}$ stress conditions. The classification of the tested hybrids was slightly changed under $\mathrm{N}$ sufficient conditions because of the high $\mathrm{N}$ induced changes in grains filling rates. The correlation analysis indicated strong positive correlation between ear yield plant ${ }^{-1}$ and grains filling rate under low $\left(r=0.97^{* \star}\right)$ and high $(r=$ $\left.0.98^{* *}\right) \mathrm{N}$ rates. Interestingly, among hybrids, the cross B73X CML103 maintained the highest ear yield with acceptable package of other flowering and physiological traits. It attained the highest values of grains filling rate $(6.87 \mathrm{~g} /$ day, low $\mathrm{N}, 6.05 \mathrm{~g} /$ day, high $\mathrm{N}$ ), moderate length of grains filling period (44.33 days), and the shortest ASI (3.67 days). These results indicate that the cross B73X CML103 has strong sink tissues, vigorous and sustainable remobilization of its metabolic resources after pollination and will be less vulnerable for pollination stress. Therefore, the cross B73X CML103
\end{abstract}


exhibits improved physiological adaptation to $\mathrm{N}$ stress and better management of its internal $\mathrm{N}$ under high $\mathrm{N}$ rate, and consequently this study recommend this cross (B73X CML103)for large scale evaluation and commercial production.

Keywords: Maize, genotypes, nitrogen, N-stress, earliness, ear, yield, light, traits

\section{INTRODUCTION}

Maize is the $3^{\text {rd }}$ most important cereal crops after wheat and rice worldwide based on productivity on area basis. It has high economic value for a wide range of human communities. It is used, as a human food, a poultry, livestock feed, and biofuel crop. It is also critical for many maize grains-based industries (Pingali and Pandey, 2001; Bello et al., 2010 and Randjelovic et al., 2011).

Maize plant's life cycle passes through two distinctive developmental processes: vegetative and reproductive stages (Potheing, 1990 and Colasanti and Muszynski, 2009) each of which has its unique physiological characteristics. During vegetative stage, the shoot apical meristem (SAM) continues to proliferate giving rise to vegetative tissues and organs. As a result, all of plant resources synthesized via plant metabolic processes such as photosynthesis are directed toward building up biomass to support the growth of the developing vegetative organs. This process continues until SAM receives flowering-inducing signals, from leaves, which provokes it to differentiate into inflorescence meristem and finally to floral organs (McSteen et al., 2000 and Colasanti and Muszynski, 2009). The performance of many flowering related traits such as dates of anthesis, silking, anthesis-silking intervals (ASI), and physiological maturity during reproductive phase significantly impact maize grains yield particularly under abiotic stress such as drought and low soil N (Schnell and Schmidt, 1975; Diallo et al., 1996; Sallah et al., 1996; Banziger et al., 2004; Derera et al., 2007; Sultan et al., 2013 and Salih et al., 2014). These traits are highly influenced by the combining ability and genetic relationships between the inbred parents (Lavergne et al., 1991; Lopes et al., 1995 and Has et al., 2012). After pollination, the pollinated ovules represent a very strong sink for various plant metabolites. As a result, intensive remobilization of metabolites takes place between source and sink tissues to support the growth of developing kernels. Consequently, both grains filling period and grains filling rate are among the most important traits that contribute significantly to both physiological maturity and the final maize grains yield (Gasura et al., 2013). Interestingly, the transition from vegetative to reproductive stages is governed by a genetic program which is regulated by genetic elements, physiological cues and environmental factors (Simpson and Dean 2002 and Jung and Muller, 2009). Understanding of such complex controlling mechanisms is far from clear (Coneva, 2012).

Significant genetic and physiological differences have been reported in earliness related traits among maize genotypes. In fact, maize genotypes have been classified into early and late genotypes based on the phenotypes of earliness related traits. Early maturing maize genotypes grow, flower, fill their kernels and reach physiological maturity faster than late genotypes (Has 
et al., 2012). These genotypes employ different physiological adaptive strategy via developing smaller areas of assimilating and vegetative tissues and direct more of their resources into grains yield which is usually lower than that of late maturing genotypes (Shaw and Thom, 1951a\&b and Dwyer et al., 1994). On the other hand, late maturing genotypes tend to have long vegetative stage as a result of investing their resources in building up more assimilating leaves and other vegetative tissues rather than in grains yield. The physiological adaption of early genotypes enables them to scape severe abiotic stresses such as drought, low temperature of approaching winter and pollination stress whereas late maturing genotypes are more vulnerable to these abiotic stresses. Because of the earliness in physiological maturity, the grains of early genotypes usually have low moisture content. On contrast, significant portion of late maturing ears either may not reach full physiological maturity or produce grains with high level of moisture which usually stimulate many storage related problems (Revilla et al., 1999). These significant differences have been driving continuous efforts of selection for maize hybrids with early flowering and physiological maturity without compromising grains yield (Laverge et al., 1991). Production of early genotypes with considerable grains yield can significantly change agricultural systems in different geographical regions. In fact, this is critical goal for maize breeders and physiologists in cold areas to avoid reduction in grains yield because of low temperature at the end of the growing season (Revilla et al., 1999). In Egypt, these early maturing crops can lead to new cropping practices via allowing the introduction of an additional crop like clover in the time gap (from September to November) between corn and wheat crops.

The earliness related traits and consequently grains yield are responsive to the nitrogenous status of the plant. In fact, nitrogen $(N)$ is the most determinant nutritive element of maize growth, development and grains yield. As a result, application of $\mathrm{N}$ fertilizers has been a common practice in modern agriculture. It is mostly supplied to the soil in the form of inorganic fertilizers and to a lesser extent as organic manure. A considerable portion of $\mathrm{N}$-fertilizer is lost to the environment through several processes such as leaching, soil denitrification, ammonia volatilization, gaseous plant emissions, and surface runoff (Akintoye et al., 1999 and Raun and Johnson, 1999). These losses stand behind the low estimate $(33 \%)$ for worldwide $\mathrm{N}$-use efficiency (NUE); a physiological traits describing the ability of maize plants to recover soil $\mathrm{N}$ for grains yield (NUE= grains yield/ $\mathrm{N}$ supplied by soil, Raun and Johnson, 1999). The production of new maize hybrids with favorable package of earliness related traits without compromising grains yield has been a continuous process (Troyer, 1986; Lopes et al., 1995 and Has et al., 2012).

In the current study, the objectives were (1) to test and evaluate possible variations of earliness related traits in a set of thirteen new developed hybrids developed by the authors, (2) examine the impact of the differences in the genetic constitutions of these hybrids on the flowering and 
physiological maturity related traits and (3) test the influence of these traits on grains yield under $\mathrm{N}$ stress and $\mathrm{N}$ sufficient conditions.

\section{MATERIALS AND METHODS}

\section{Genetic materials, field design and treatments:}

Five local commercial single crosses and thirteen newly developed hybrids formed the genetic materials of the current study. The local single crosses namely Pioneer SC 3084, SC 168, SC 167, SC 173 and SC 10 were developed by the Egyptian Agricultural Research Center and are recommended to the farmers by the Egyptian Ministry of Agriculture and Land Reclamation. The remaining thirteen hybrids are new and are developed by the authors (Abdel-Moneam and Ibraheem, 2015). These new hybrids are single crosses with a common female inbred parent (B73) that was crossed to a number of American and Egyptian inbred lines belonging to different heterotic groups. The field tests were performed in the farm of the Department of Botany, Mansoura University, Mansoura, Egypt during the summer of the 2012 growing season. The experimental design was complete randomized block with three replicates for each low and high nitrogen fertlilization. Experimental unit had four ridges for each hybrid. Hybrid seeds were sown, two seeds per hill, on May, 24 with a space of approximately 25 $\mathrm{cm}$ between plants in rows of 3 meter long and $70 \mathrm{~cm}$ apart. At two leaf stage, plants were thinned to one secure plant per hill. At growth stage of three leaves, the plots of the first experiment of low $\mathrm{N}$ received ammonium nitrate fertilizer (33.3\%) at level of $30 \mathrm{~kg} \mathrm{~N} /$ faddan down the center of the row, whereas the second experiment was marked high $\mathrm{N}$ and received $120 \mathrm{~kg} \mathrm{~N}$ /faddan (Ritchie et al., 1997). Plants were irrigated every 10 days till physiological maturity. Weather conditions were favorable to all tested hybrids to reach physiological maturity.

\section{Studied traits:}

To evaluate the field performance of the newly developed hybrids under $\mathrm{N}$ stress and $\mathrm{N}$ sufficient conditions, the flowering traits, flowering and maturity- related physiological traits, and ear yield of these hybrids along with five check hybrids were monitored. Measurements of each trait was recorded when $50 \%$ of plants in each plot showed the phenotype of the investigated trait.

\section{Investigation of flowering traits:}

These traits included anthesis date, dates of silking emergence (silking date), and anthesis silking intervals. The anthesis date (days) was recorded as the number of days from sowing to pollen shed on $50 \%$ of plants/ plot. Silking date was monitored by recording the number of days from sowing to silk extrusion of $50 \%$ of plants/ plot. The Anthesis- Silking Interval (ASI, days) was calculated as the number of days from approaching $50 \%$ anthesis to $50 \%$ silking of plants in each subplot.

Investigation of flowering and maturity related physiological traits:

These traits included physiological maturity, grains filling period, grains filling rate, and the efficiency of absorption of solar radiation by plant cover of the tested hybrids. The physiological maturity trait was monitored by 
calculating the number of days from sowing date to the date of reaching physiological maturity which is indicated by forming black layer at the base of kernels. Grains filling period was examined by calculating the number of days from silking date to physiological maturity date. Grains filling rate (g/day) was determined via monitoring the amount of dry weight deposited into grains throughout the grains filling period. This was calculated by dividing the harvested grains weight (grams) by the duration of the grains filling period (days). The efficiency of absorption of solar radiation by plant cover of the tested hybrids were monitored indirectly by measuring the effects of leaf area index on the amount of light absorbed by plants using the equation $" I_{A}=1-\mathrm{e}$

k $\times$ LAl" as described by Tollenaar et al. (2004) where $I_{A}$ represents the fraction of incident solar radiation absorbed by the tested plants, and $k$ is the extinction coefficient of the plant cover. The extinction coefficient (k) was assumed to be 0.65 in the estimates of light interception.

Investigation of yield in the tested hybrids:

To test the impact of possible difference in the above mentioned traits on the yield of the tested hybrids, ear yield of these hybrids was monitored. This was carried out by recording ear yield plant $^{-1}$ by weighing the dehusked ears of plants for each plot at harvest.

Statistical analysis:

An analysis of variance was performed separately for each experiment of nitrogen levels (low and high $\mathrm{N}$ ) and combined analysis over both these experiments of low and high nitrogen according to randomized complete block design with three replicates using Mstatc program. Differences were compared using the least significant difference (LSD) test at the 0.05 level of significance.

\section{RESULTS AND DISCUSSION}

\section{Analysis of variance:}

Analysis of variance of single and combined analysis for the studied traits is presented in Table1. Results indicated that $\mathrm{N}$-treatments mean squares were either significant or highly significant for all studied traits, indicating significant differences between the two nitrogen fertilization rates for all studied characters. Intestinally, mean squares of crosses were also highly significant for all studied traits under both low and high $\mathrm{N}$ fertilization rates and their combined analysis, indicating significant genotypic differences among the studied crosses. The $\mathrm{N}$-treatments $\times$ crosses interaction mean squares were found to be significant or highly significant for all studied traits, indicating that these traits were influenced significantly by both environmental conditions ( $\mathrm{N}$ rates) and genetic constitution of the tested hybrids (maize crosses). These results are in agreement with those obtained by AbdelMonaem, (2000), Saeid et al., (2010), Bello et al., (2012), El- Badawy, (2013) and Sultan et al., (2013). 
Table, 1: Mean squares from analysis of variance, for maize flowering and earliness traits under both low and high nitrogen fertilization levels and their combined analysis.

\begin{tabular}{|c|c|c|c|c|c|c|c|c|}
\hline \multirow{2}{*}{ S.O.V } & \multicolumn{2}{|c|}{ d f f } & \multicolumn{3}{|c|}{ Anthesis date, day } & \multicolumn{3}{|c|}{ Silking date, day } \\
\hline & Single & Comb. & Low N & High N & Comb. & Low $\mathrm{N}$ & High N & Comb. \\
\hline N-treatments & - & 1 & - & - & $48.04^{* *}$ & - & - & $46.75^{\star *}$ \\
\hline Error & - & 4 & - & - & 0.596 & - & - & 0.325 \\
\hline Crosses & 17 & 17 & $160.2^{\star *}$ & $181.9^{* *}$ & $332.3^{\star \star}$ & $170.9^{\star *}$ & $185.9^{\star \star}$ & $347.3^{\star \star}$ \\
\hline $\mathrm{N} \times \mathrm{C}$ & - & 17 & - & - & $3.74^{\star \star}$ & - & - & $1.60^{*}$ \\
\hline Error & 34 & 68 & 1.045 & 0.60 & 0.800 & 0.947 & 0.814 & 0.880 \\
\hline \multirow[t]{2}{*}{ S.O.V } & \multicolumn{2}{|c|}{$d f$} & \multicolumn{3}{|c|}{$\begin{array}{l}\text { Anthesis-Silking Interval } \\
\text { (ASI), day }\end{array}$} & \multicolumn{3}{|c|}{ Maturity date, day } \\
\hline & Single & Comb. & Low N & High N & Comb. & Low $\mathrm{N}$ & High N & Comb. \\
\hline $\mathrm{N}$-treatments & - & 1 & - & - & $189.6^{* \star}$ & - & - & $926.5^{\star \star}$ \\
\hline Error & - & 4 & - & - & 0.491 & - & - & 21.14 \\
\hline Crosses & 17 & 17 & $3.775^{\star \star}$ & $1.499^{* *}$ & $2.55^{\star \star}$ & $156.9^{* \star}$ & $160.9^{\star *}$ & $338.5^{\star \star}$ \\
\hline $\mathrm{NXC}$ & - & 17 & - & - & $2.50^{* *}$ & - & - & $1.67^{\star *}$ \\
\hline Error & 34 & 68 & 0.814 & 0.499 & 0.639 & 0.358 & 0.541 & 0.437 \\
\hline \multirow{2}{*}{ S.O.V } & \multicolumn{2}{|c|}{$d f$} & \multicolumn{3}{|c|}{ Grains filling period, day } & \multicolumn{3}{|c|}{ Grains filling rate, g/day } \\
\hline & Single & Comb. & Low N & High N & Comb. & Low $\mathrm{N}$ & High N & Comb. \\
\hline $\mathrm{N}$-treatments & - & 1 & - & - & $1389^{* *}$ & - & - & $3.16^{* *}$ \\
\hline Error & - & 4 & - & - & 17.851 & - & - & 0.118 \\
\hline Crosses & 17 & 17 & $21.14^{\star \star}$ & $20.89^{* \star}$ & $46.6^{* \star}$ & $5.13^{\star *}$ & $4.107^{\star \star}$ & $7.68^{\star \star}$ \\
\hline $\mathrm{NXC}$ & - & 17 & - & - & 1.305 & - & - & $1.38^{\star \star}$ \\
\hline Error & 34 & 68 & 1.045 & 1.603 & 1.268 & 0.011 & 0.017 & 0.013 \\
\hline \multirow[t]{2}{*}{ S.O.V } & \multicolumn{2}{|c|}{$d f$} & \multicolumn{3}{|c|}{ Ear yield plant ${ }^{-1}, \mathrm{~g}$} & \multicolumn{3}{|c|}{$\begin{array}{l}\text { The fraction of incident solar } \\
\text { radiation absorbed }\left(I_{A}\right)\end{array}$} \\
\hline & Single & Comb. & Low N & High N & Comb. & Low N & High N & Comb. \\
\hline $\mathrm{N}$-treatments & - & 1 & - & - & $61229^{\star *}$ & - & - & 0.006 \\
\hline Error & - & 4 & - & - & 19.654 & - & - & 0.002 \\
\hline Crosses & 17 & 17 & $12795^{\star \star}$ & $14159^{\star \star}$ & $23978^{* *}$ & $0.007^{*}$ & $0.002^{\star \star}$ & $0.006^{* *}$ \\
\hline $\mathrm{N} \times \mathrm{C}$ & - & 17 & - & - & $3192^{\star *}$ & - & - & 0.002 \\
\hline Error & 34 & 68 & 11.476 & 0.001 & 5.452 & 0.004 & 0.000 & 0.002 \\
\hline
\end{tabular}

$\left({ }^{*}\right)$ and $\left(^{\star *}\right)$ significant at 0.05 and 0.01 levels probability, respectively.

\section{Mean performance of crosses:}

For anthesis and silking dates (days), results in Table 2 showed that the studied crosses had highly significant differences in anthesis and silking dates under both low and high nitrogen conditions and their combined data. The number of days from sowing to anthesis varied over a range from 50 to 71.67 days and from 50.67 to 72.67 days under low and high $\mathrm{N}$ respectively. The number of days from sowing to silk emergence changed from 54.67 to 76 days and from 53 to 75 days under limited and sufficient $N$ conditions respectively. Interestingly, most of the new hybrids exhibited earlier anthesis and silking dates than all check crosses under both $\mathrm{N}$ rates. Out of the thirteen tested new hybrids, four crosses, namely B73X Phg47, B73X HP301, B73X PH207 and B73X PHj40 recorded the lowest number of days from sowing to $50 \%$ pollen shedding and silking and significantly surpassed over both the rest of the new hybrids and all studied check crosses (Pioneer SC 
3084, SC 168, SC 167, SC 173 and SC 10) under both $\mathrm{N}$ rates and their combined data in earliness of anthesis and silking. As a result they were ranked the earliest crosses in these two traits. Among the tested check crosses, the crosses SC10, SC167, SC168 and SC 173 were the latest in anthesis and silking under both low and high nitrogen conditions and their combined data. The rest of the tested hybrids exhibited intermediate anthesis and flowering dates.

Table 2: Mean performance of maize crosses for anthesis date (day) and silking date (day) under low and high nitrogen fertilization levels and their combined data.

\begin{tabular}{|l|c|c|c|c|c|c|}
\hline \multirow{2}{*}{$\begin{array}{l}\text { Trait } \\
\text { Cross }\end{array}$} & \multicolumn{3}{|c|}{ Days to Anthesis } & \multicolumn{3}{c|}{ Days to Silking } \\
\cline { 2 - 7 } 1-B73X Phg47 & Low N & High N & Comb. & Low N & High N & Comb. \\
\hline 2-B73X B97 & 57.00 & 50.67 & 50.33 & 54.67 & 53.00 & 53.83 \\
\hline 3-B73X PHj40 & 53.00 & 55.33 & 56.33 & 61.33 & 58.00 & 59.67 \\
\hline 4-B73X PH207 & 52.67 & 54.00 & 53.33 & 58.00 & 56.00 & 57.00 \\
\hline 5-B73X HP301 & 51.00 & 53.33 & 52.17 & 57.00 & 55.33 & 56.67 \\
\hline 6-B73X CML103 & 57.00 & 54.67 & 55.83 & 60.67 & 58.33 & 59.17 \\
\hline 7-B73X TZI8 & 57.00 & 56.00 & 56.50 & 61.00 & 59.67 & 60.33 \\
\hline 8-B73X NC358 & 53.00 & 55.33 & 54.17 & 58.33 & 57.33 & 57.83 \\
\hline 9-B73X Mo17 & 54.67 & 57.00 & 55.83 & 58.67 & 59.67 & 59.17 \\
\hline 10-B73X Inb209 & 62.67 & 66.00 & 64.33 & 68.67 & 68.00 & 68.33 \\
\hline 11-B73X Sids63 & 62.67 & 64.33 & 63.50 & 67.00 & 67.33 & 67.17 \\
\hline 12-B73X Rg5 & 60.33 & 62.67 & 61.50 & 65.00 & 64.00 & 64.50 \\
\hline 13-B73X Inb.204 & 65.33 & 67.00 & 66.17 & 72.67 & 70.33 & 71.50 \\
\hline 14-SC3084(check) & 66.33 & 68.67 & 67.50 & 73.33 & 71.67 & 72.50 \\
\hline 15-SC168(check) & 70.67 & 72.67 & 71.67 & 75.33 & 74.67 & 75.00 \\
\hline 16-SC167(check) & 71.67 & 72.33 & 72.00 & 75.67 & 74.67 & 75.17 \\
\hline 17-SC173(check) & 67.33 & 70.33 & 68.83 & 74.00 & 73.67 & 73.83 \\
\hline 18-SC10 (check) & 71.67 & 72.67 & 72.17 & 76.00 & 75.00 & 75.50 \\
\hline Mean & 60.24 & 61.48 & 60.86 & 65.29 & 64.00 & 64.65 \\
\hline LSD at 0.05 & 2.885 & 2.201 & 2.522 & 2.779 & 2.600 & 2.645 \\
\hline LSD at 0.05 (NXC) & \multicolumn{2}{|c|}{1.48} & - & & 1.53 & - \\
\hline
\end{tabular}

$\mathrm{N}$ - treatment also induced significant differences in anthesis and silking dates in a number of hybrids. For example, high $\mathrm{N}$ treatment increased the number of days required for anthesis of ten hybrids. These hybrids included seven new hybrids namely B73X HP301, B73X NC358, B73X Mo17, B73X Inb209, B73X Sids63, B73X Rg5 and B73X Inb.204 as well as three check crosses namely SC3084, 15-SC168, SC173. Among these ten hybrids, the magnitude of high $\mathrm{N}$ induced-anthesis earliness ranged from 1.66 to 3.0 days. On the other hand, high $\mathrm{N}$ treatment reduced the number of days needed for anthesis of two hybrids B73X B97 and B73X CML103 by 2.0 and 2.33 days respectively. High $\mathrm{N}$ treatment exhibited no significant effect on the anthesis of the rest of the tested hybrids. Regarding the influence of high $\mathrm{N}$ treatment on silking dates, the results indicated that, high $\mathrm{N}$ fertilization generally decreased number of days required for silking in seven new hybrids 
including B73X Phg47, B73X B97, B73X PHj40, B73X PH207, B73X HP301, B73X CML103 and B73X Inb.204 as well as only SC3084 from check hybrids. However the tested hybrids exhibited significant difference in the extent of such high $\mathrm{N}$ induced reduction in this trait where it ranged from 3.33 to -1.66 days.

With respect to anthesis-silking interval (ASI), results in Table 3 revealed that the studied crosses exhibited highly significant differences in anthesis-silking interval (ASI) trait under both low and high nitrogen conditions and their combined data. The ASI of the tested crosses varied over a range from 4 to 7 days, and from 1.33 to 5.33 days under low $N$ and high $\mathrm{N}$, respectively. The lowest values of ASI were recorded by five crosses namely B73X CML103, B73X TZI8, SC167 (check), B73X Mo17 and B73X B97 under low N level fertilization conditions with B73X CML103 attaining the shortest ASI (3.66 days). On the other hand, crosses B73X Inb.204 and SC 3084 (check) attained the highest values of ASI (7 days) among hybrids under low rate of $\mathrm{N}$ fertilization. Under $\mathrm{N}$ sufficient conditions, two crosses namely B73X PH207 and B73X Rg5 attained the lowest values of ASI whereas crosses B73X CML103 and B73X TZI8 exhibited the highest ASI values among hybrids. In the combined analysis, our results showed that the cross B73X Rg5 recorded the lowest ASI values among hybrids. On the contrary, four crosses i.e. B73X Inb.204, SC168 SC 3084 and SC173 recorded the highest ASI values among hybrids. High $\mathrm{N}$ treatment induced general reduction of ASI in all tested hybrids. However, significant differences were observed in the magnitude of such high $\mathrm{N}$-induced reduction in the time length of $\mathrm{ASI}$ where it varied over a range from -1.33 to -4.0 days among responsive hybrids.

For physiological maturity date (days), results in Table 3 showed highly significant differences in maturity date among the tested hybrids under both low and high $\mathrm{N}$ conditions and their combined data. The number of days needed for reaching physiological maturity of the tested hybrids ranged from 95.67 to 117 and 100 to 122 days under $\mathrm{N}$ stress and $\mathrm{N}$ sufficient conditions, respectively. Interestingly, two crosses namely B73X PHj40 and B73X HP301 consistently maintained the lowest number of days required from sowing to achieve physiological maturity among hybrids under both $\mathrm{N}$ treatments and in the combined analysis. These two hybrids significantly surpassed all new hybrids as well as check crosses (Pioneer SC 3084, SC 168, SC 167, SC 173 and SC 10) and consequently were ranked the earliest crosses in maturity among hybrids. On the other hand, three check crosses SC10, SC167 and SC168 were the latest crosses in maturity date under both low and high $\mathrm{N}$ conditions and their combined data. Interestingly, most of the rest of the tested hybrids exhibited intermediate physiological maturity dates with three distinctive subgroups. The first subgroup included crosses B73X Phg47, B73X B97, B73X PH207, B73X TZI8, B73X NC358, and B73X Mo17 showed similar response under low and high $\mathrm{N}$ rates with about 101 and 106 days for physiological maturity, respectively. The second subgroup included only B73XCML103 with number of days of 105 and 110 for achieving physiological maturity under $\mathrm{N}$ stress and $\mathrm{N}$ sufficient conditions, 
respectively. On the other hand, the third subgroup included B73X Inb209, B73X Sids63, B73X Rg5, and SC173 with number of days required for physiological maturity from $\sim 110.1$ to $\sim 116$ under low and high $\mathrm{N}$ rates, respectively. In both new hybrids and the check crosses, high $\mathrm{N}$ induced general increase in the number of days required to achieve physiological maturity. However the tested hybrids differed in the extent of such increase which fluctuated over a range from 4.33 to 7.70 days.

Table, 3: Mean performance of maize crosses for anthesis-silking interval (ASI) and maturity date under low and high nitrogen fertilization levels and their combined data.

\begin{tabular}{|l|c|c|c|c|c|c|}
\hline \multirow{2}{*}{$\begin{array}{l}\text { Trait } \\
\text { Cross }\end{array}$} & \multicolumn{3}{|c|}{$\begin{array}{c}\text { Anthesis-Silking Interval } \\
\text { (ASI), day }\end{array}$} & \multicolumn{3}{c|}{ Maturity date, day } \\
\cline { 2 - 7 } & Low N & High N & Comb. & Low N & High N & Comb. \\
\hline 1-B73X Phg47 & 4.67 & 2.33 & 3.5 & 101.0 & 106.0 & 103.5 \\
\hline 2-B73X B97 & 4.00 & 2.67 & 3.33 & 101.0 & 106.0 & 103.5 \\
\hline 3-B73X PHj40 & 5.00 & 2.33 & 3.67 & 95.67 & 100.0 & 97.83 \\
\hline 4-B73X PH207 & 5.33 & 1.33 & 3.33 & 101.3 & 106.0 & 103.7 \\
\hline 5-B73X HP301 & 6.00 & 2.00 & 4.00 & 95.67 & 103.0 & 99.33 \\
\hline 6-B73X CML103 & 3.67 & 3.67 & 3.67 & 105.0 & 110.0 & 107.5 \\
\hline 7-B73X TZI8 & 4.00 & 3.67 & 3.83 & 101.0 & 106.0 & 103.5 \\
\hline 8-B73X NC358 & 5.33 & 2.00 & 3.67 & 101.0 & 107.0 & 104.0 \\
\hline 9-B73X Mo17 & 4.00 & 2.67 & 3.33 & 101.0 & 107.7 & 104.3 \\
\hline 10-B73X Inb209 & 6.00 & 2.00 & 4.00 & 110.0 & 117.7 & 113.8 \\
\hline 11-B73X Sids63 & 4.33 & 3.00 & 3.67 & 111.0 & 118.3 & 114.7 \\
\hline 12-B73X Rg5 & 4.67 & 1.33 & 3.00 & 110.0 & 114.7 & 112.3 \\
\hline 13-B73X Inb.204 & 7.33 & 3.33 & 5.33 & 115.0 & 119.7 & 117.3 \\
\hline 14-SC3084(check) & 7.00 & 3.00 & 5.00 & 114.7 & 120.7 & 117.7 \\
\hline 15-SC168(check) & 4.67 & 2.00 & 3.33 & 116.3 & 121.7 & 119.0 \\
\hline 16-SC167(check) & 4.00 & 2.33 & 3.17 & 115.0 & 120.3 & 117.7 \\
\hline 17-SC173(check) & 6.67 & 3.33 & 5.00 & 110.0 & 116.7 & 113.3 \\
\hline 18-SC10 (check) & 4.33 & 2.33 & 3.33 & 117.0 & 122.0 & 119.5 \\
\hline Mean & 5.06 & 2.52 & 3.79 & 106.76 & 112.41 & 109.58 \\
\hline LSD at 0.05 & 2.531 & 2.028 & 2.254 & 1.694 & 2.076 & 1.864 \\
\hline LSD at 0.05 (NXC) & \multicolumn{2}{|c|}{1.32} & - & & 1.09 & - \\
\hline
\end{tabular}

For grains filling period (days), results in Table 4 showed that the studied crosses had highly significant differences in grains filling period trait under both low and high nitrogen conditions and their combined data. The tested hybrids exhibited grains filling period ranges from 36 to 46.33 days and 43 to 53 days under $\mathrm{N}$ stress and $\mathrm{N}$ sufficient conditions, respectively. Interestingly, the two crosses SC173, and B73X PHj40 consistently maintained the shortest grains filling period under all tested conditions without significant difference between both hybrids under each $\mathrm{N}$ treatment and in the combined analysis. On the other hand, the hybrids B73X Rg5, B73X Sids63, B73XCML103, and B73X Phg47 tended to consistently have the longest grains filling period without significant differences among them under low $\mathrm{N}$, 
high $\mathrm{N}$ conditions and in the combined analysis. The rest of the hybrids showed intermediate grains filling period. High $\mathrm{N}$ fertilization induced general increase in the length of the grains filling period in all tested hybrids. The extent of such increases changed over a range from 5.67 to 9.0 days reflecting significant differences among most of the tested hybrids. The hybrids B73X HP301, B73X B97 and B73X Inb209 were the highest responsive whereas hybrids $B 73 X$ Mo17 and $B 73 X$ Rg5 exhibited the lowest response to high $\mathrm{N}$ fertilization. The rest of hybrids showed intermediate response to high $\mathrm{N}$ fertilization.

With respect to grains filling rate, g/day, results in Table 4 showed that the studied crosses had highly significant differences in grains filling rate trait under both low and high nitrogen conditions and their combined analysis. The grains filling rate of the tested hybrids changed from 1.443 to 6.873 and from 1.883 to 6.047 gram/day under $\mathrm{N}$ stress and $\mathrm{N}$ sufficient conditions, respectively. Based on the values of individual and mean grains filling rates, the tested hybrids can be roughly categorized into three subgroups: slow rate grains filler ( $\leq 1.4$ to $3.5 \mathrm{~g} /$ day, e.g. B73X HP301, B73X PHj40 and B73X $\mathrm{PH} 207$ ), intermediate rate grains filler (3.5 to $4.5 \mathrm{~g} /$ day, e.g. B73X Phg47, B73X B97, B73X Mo17, B73X Inb209, B73X Sids63, B73X Rg5, B73X Inb.204, SC3084, SC168, SC167, SC173, and SC10) and rapid rate grains filler (4.5 to $\geq 6$ gram/day, e.g. B73X CML103, B73X TZI8 and B73X NC358) under $\mathrm{N}$ stress conditions. The classification of the tested hybrids was slightly changed under $\mathrm{N}$ sufficient conditions because of the high $\mathrm{N}$ induced changes in grains filling rates. For example, crosses B73X Sids63, B73X Inb.204, and SC10 moved to rapid grains filler group in response to high $\mathrm{N}$ fertilization. Interestingly, the crosses B73X CML103, B73X TZI8 and B73X NC358, consistently exhibited the highest values of grains filling rate and significantly surpassed over other new hybrids and all check crosses, with significant differences between them under each $\mathrm{N}$ treatment and in the combined analysis. On the other hand, crosses B73X HP301, B73X PHj40 and $\mathrm{B} 73 \mathrm{X} \mathrm{PH} 207$ tended to have the lowest values of grains filling rate under both low and high $\mathrm{N}$ levels and their combined analysis. Among the tested check crosses, the cross SC10 (check) showed the highest grains filling rate (5.83 g/day) under high $\mathrm{N}$ level. It is important to point out that high $\mathrm{N}$ treatment induced significant changes in the grains filling rate in most of the tested hybrids. However, these high $\mathrm{N}$-induced changes showed some interesting fluctuations among hybrids. For example, nine hybrids namely B73X PHj40, B73X HP301, B73X Mo17, B73X Inb209, B73X Sids63, B73X Inb.204, SC168, SC167 and SC10 showed positive response in their grains filling rate under high $\mathrm{N}$ conditions as compared to $\mathrm{N}$ limited conditions with B73X Sids63 being the highest responsive hybrid. On the other hand, seven hybrids including B73X B97, B73X CML103, B73X TZI8, B73X NC358, B73X Rg5, SC3084 and SC173 exhibited negative response to high N conditions as compared to low $\mathrm{N}$ rate with $\mathrm{B} 73 \mathrm{X} \mathrm{CML} 103$ being superior to the rest of hybrids in this group. The two hybrids, B73X Phg47 and B73X B97 showed non-significant response to sufficient $\mathrm{N}$ fertilization compared to limited $\mathrm{N}$ rate. 
Table 4: Mean performance of maize crosses for grains filling period (day) and grains filling rate (g/day) under low and high nitrogen fertilization levels and their combined data.

\begin{tabular}{|l|c|c|c|c|c|c|}
\hline \multirow{2}{*}{$\begin{array}{l}\text { Trait } \\
\text { Cross }\end{array}$} & \multicolumn{2}{|c|}{ Grains filling period, days } & \multicolumn{3}{c|}{ Grains filling rate, g/day } \\
\cline { 2 - 7 } Low N & High N & Comb. & Low N & High N & Comb. \\
\hline 1-B73X Phg47 & 46.33 & 53.00 & 49.67 & 4.217 & 4.240 & 4.228 \\
\hline 2-B73X B97 & 39.67 & 48.00 & 43.83 & 4.030 & 3.660 & 3.845 \\
\hline 3-B73X PHj40 & 37.67 & 44.00 & 40.83 & 2.393 & 2.630 & 2.512 \\
\hline $4-B 73 X$ PH207 & 43.33 & 50.67 & 47.00 & 2.623 & 2.583 & 2.603 \\
\hline 5-B73X HP301 & 38.67 & 47.67 & 43.17 & 1.443 & 1.883 & 1.663 \\
\hline 6-B73X CML103 & 44.33 & 51.67 & 48.00 & 6.873 & 6.047 & 6.460 \\
\hline 7-B73X TZI8 & 40.00 & 46.33 & 43.17 & 5.773 & 5.283 & 5.528 \\
\hline 8-B73X NC358 & 42.67 & 49.67 & 46.17 & 4.860 & 4.633 & 4.747 \\
\hline 9-B73X Mo17 & 42.33 & 48.00 & 45.17 & 2.747 & 4.120 & 3.433 \\
\hline 10-B73X Inb209 & 41.33 & 49.67 & 45.50 & 2.380 & 3.083 & 2.732 \\
\hline 11-B73X Sids63 & 44.00 & 51.00 & 47.50 & 2.547 & 5.233 & 3.890 \\
\hline 12-B73X Rg5 & 45.00 & 50.67 & 47.83 & 3.550 & 3.270 & 3.410 \\
\hline 13-B73X Inb.204 & 42.33 & 49.33 & 45.83 & 4.250 & 5.453 & 4.852 \\
\hline 14-SC3084(check) & 41.33 & 49.00 & 45.17 & 4.217 & 3.707 & 3.962 \\
\hline 15-SC168(check) & 41.00 & 47.00 & 44.00 & 4.067 & 4.323 & 4.195 \\
\hline 16-SC167(check) & 39.33 & 45.67 & 42.50 & 4.023 & 4.457 & 4.240 \\
\hline 17-SC173(check) & 36.00 & 43.00 & 39.50 & 4.160 & 3.873 & 4.017 \\
\hline 18-SC10 (check) & 41.00 & 47.00 & 44.00 & 3.500 & 5.833 & 4.667 \\
\hline Mean & 41.46 & 48.41 & 44.94 & 3.76 & 4.13 & 3.94 \\
\hline LSD at 0.05 & 2.867 & 3.555 & 3.175 & 0.3008 & 0.3628 & 0.3214 \\
\hline LSD at 0.05 (NXC) & \multicolumn{2}{|c|}{1.87} & - & & 0.19 & - \\
\hline
\end{tabular}

For ear yield plant ${ }^{-1}$, results in Table 5 revealed that the studied crosses had highly significant differences in ear yield plant ${ }^{-1}$ under both low and high $\mathrm{N}$ conditions and their combined data. The ear yield plant ${ }^{-1}$ of the tested crosses changed over a range from 121.6 to 372.1 and from 123.3 to $381.2 \mathrm{~g} /$ plant under limited and sufficient $\mathrm{N}$, respectively. Cross B73X CML103 followed by B73X TZI8 and B73X NC358 exhibited the highest ear yield plant ${ }^{-1}$ under both low $\mathrm{N}$ rate and combined analysis. Under high $\mathrm{N}$ fertilization, cross B73X CML103 followed by SC10 (check) and B73X Sids63 recorded the highest values of ear yield plant ${ }^{-1}$ and significantly surpassed over the other studied new crosses as well as the other studied check crosses (Pioneer SC 3084, SC 168, SC 167, SC 173). On the other hand, crosses B73X PHj40, B73X PH207 and B73X HP301 attained the lowest ear yield plant ${ }^{-1}$ under low $\mathrm{N}$ conditions and combined analysis whereas crosses B73X HP301 and B73X PHj40 exhibited the lowest ear yield plant ${ }^{-1}$ under high $\mathrm{N}$ conditions. The rest of the tested hybrids attained intermediate ear yield plant $^{-1}$ under different $\mathrm{N}$ treatments. High $\mathrm{N}$ treatment induced general significant increase in ear yield plant ${ }^{-1}$ in all tested hybrids. However significant difference in the magnitude of such high $\mathrm{N}$-induced yield increase among hybrids were observed where it changed over a range of 2.45 to 
$126.71 \%$ as compared to the yield under $\mathrm{N}$ stress conditions. The highest high $\mathrm{N}$-induced yield increase was recorded by hybrid B73X Sids63 (126\%) whereas the lowest was attained by B73X CML103 (2.45\%).

Table, 5: Mean performance of maize crosses for ear yield plant ${ }^{-1}$ under low and high nitrogen fertilization levels and their combined data.

\begin{tabular}{|c|c|c|c|}
\hline Trait & & ield pla & \\
\hline Cross & Low N & High N & Comb. \\
\hline 1-B73X Phg47 & 223.7 & 265.0 & 244.4 \\
\hline 2-B73X B97 & 183.3 & 215.3 & 199.3 \\
\hline 3-B73X PHj40 & 121.6 & 153.3 & 137.5 \\
\hline 4-B73X PH207 & 137.5 & 158.3 & 147.9 \\
\hline 5-B73X HP301 & 90.73 & 123.3 & 107.0 \\
\hline 6-B73X CML103 & 372.1 & 381.2 & 376.7 \\
\hline 7-B73X TZI8 & 281.1 & 300.2 & 290.7 \\
\hline 8-B73X NC358 & 262.7 & 282.6 & 272.7 \\
\hline 9-B73X Mo17 & 168.2 & 228.0 & 198.1 \\
\hline 10-B73X Inb209 & 139.8 & 187.5 & 163.7 \\
\hline 11-B73X Sids63 & 140.4 & 318.3 & 229.4 \\
\hline 12-B73X Rg5 & 180.6 & 202.4 & 191.5 \\
\hline 13-B73X Inb.204 & 218.3 & 315.2 & 266.8 \\
\hline 14-SC3084(check) & 215.0 & 228.5 & 221.8 \\
\hline 15-SC168(check) & 217.2 & 255.2 & 236.2 \\
\hline 16-SC167(check) & 199.7 & 257.8 & 228.8 \\
\hline 17-SC173(check) & 184.3 & 199.1 & 191.7 \\
\hline 18-SC10 (check) & 184.8 & 327.8 & 256.3 \\
\hline Mean & 195.62 & 244.41 & 220.01 \\
\hline LSD at 0.05 & 9.471 & 0.091 & 6.583 \\
\hline LSD at 0.05 (NXC) & & & - \\
\hline
\end{tabular}

For the fraction of incident solar radiation absorbed $\left(I_{A}\right)$, results in Table 6 revealed that the studied crosses tended to have slight differences in $\left(I_{A}\right)$ under both low and high $\mathrm{N}$ conditions and their combined data. The $\left(I_{A}\right)$ of the tested crosses changed over a range from 0.802 to 0.996 and from 0.911 to 0.998 under limited and sufficient $\mathrm{N}$, respectively. The check crosses (Pioneer SC 3084, SC 168, SC 167, SC 173) as well as the new hybrid B73X Inb.204 tended to have the highest $I_{A}$ value among crosses under deficient and sufficient $\mathrm{N}$ conditions without significant differences among them. On the other hand, crosses B73X Mo17, B73X PH207, B73X PHj40, B73X PHG47, B73X 97, and B73X HP301 attained lower ranking based on their $I_{A}$ values under both $\mathrm{N}$ rates with $\mathrm{B} 73 \mathrm{X}$ Mo17 being the lowest among them. The rest of the studied hybrids showed intermediate $I_{A}$ values. High $N$ treatment tended to induce slight increase in the measured $I_{A}$ value regardless the genotype tested. 
Table, 6: Mean performance of maize crosses for the fraction of incident solar radiation absorbed $\left(I_{A}\right)$ under low and high nitrogen fertilization levels and their combined data.

\begin{tabular}{|c|c|c|c|}
\hline Trait & The fractiol & it solar I & sorbed $\left(I_{A}\right)$ \\
\hline Cross & Low N & High N & Comb. \\
\hline 1-B73X PHG47 & 0.939 & 0.962 & 0.951 \\
\hline 2-B73X B97 & 0.954 & 0.965 & 0.96 \\
\hline 3-B73X PHj40 & 0.924 & 0.923 & 0.923 \\
\hline 4-B73X PH207 & 0.904 & 0.911 & 0.907 \\
\hline 5-B73X HP301 & 0.971 & 0.981 & 0.976 \\
\hline 6-B73X CML103 & 0.99 & 0.994 & 0.992 \\
\hline 7-B73X Tzi8 & 0.974 & 0.991 & 0.982 \\
\hline 8-B73X NC358 & 0.973 & 0.981 & 0.977 \\
\hline 9-B73X Mo17 & 0.802 & 0.970 & 0.886 \\
\hline 10-B73X Inb209 & 0.972 & 0.981 & 0.977 \\
\hline 11-B73X Sids63 & 0.985 & 0.987 & 0.986 \\
\hline 12-B73X Rg5 & 0.975 & 0.980 & 0.978 \\
\hline 13-B73X Inb.204 & 0.989 & 0.990 & 0.989 \\
\hline 14-SC3084(check) & 0.995 & 0.997 & 0.996 \\
\hline 15-SC168 (check) & 0.995 & 0.998 & 0.996 \\
\hline 16-SC167 (check) & 0.996 & 0.997 & 0.996 \\
\hline 17-SC173 (check) & 0.988 & 0.992 & 0.99 \\
\hline 18-SC10 (check) & 0.995 & 0.998 & 0.996 \\
\hline Mean & 0.962 & 0.977 & 0.97 \\
\hline LSD at 0.05 & 0.099 & 0.013 & 0.049 \\
\hline LSD at 0.05 (NXC) & & & - \\
\hline
\end{tabular}

\section{Correlation between ear yield and studied earliness traits:}

Correlation coefficients between ear yield plant $^{-1}$ and the rest of other studied traits are shown in Table 7. The results indicated that ear yield was positively correlated to all tested traits $(p=0.05)$ under both low and high $\mathrm{N}$ conditions, except anthesis date and silking date under both conditions and anthesis-silking interval (ASI) and maturity date under low $\mathrm{N}$ conditions. However, the magnitude of such correlation differed significantly among traits under low $\mathrm{N}$ and high $\mathrm{N}$ input. For example, ear yield was highly correlated with grains filling rate under both low $\mathrm{N}$ and high $\mathrm{N}\left(\mathrm{r}=0.97^{\star *}\right.$ and $\mathrm{r}=0.98^{\star *}$ respectively). The correlation coefficients were positive and moderate between ear yield and grains filling period $\left(r=0.36^{*}\right.$ and $\left.r=0.39^{*}\right)$ under both low and high $\mathrm{N}$ levels, respectively, as well as with anthesis-silking interval (ASI) $\left(r=57^{*}\right)$, the fraction of incident solar radiation absorbed $\left(I_{A}\right)\left(r=0.56^{*}\right)$ and maturity date $\left(r=0.45^{*}\right)$ under high $\mathrm{N}$ only. On the other hand, ear yield exhibited positive non-significant correlation with anthesis and silking dates under both $\mathrm{N}$ rates and negative non-significant correlation with ASI under low $\mathrm{N}$ rate.

Altogether, these results suggest that, in general, to increase ear yield plant $^{-1}$, selection should be carried out for some earliness traits such as grains filling rate and physiological maturity under both low and high $\mathrm{N}$ 
conditions. The correlation between ear yield and the investigated traits in the tested genotypes suggests that selection for earliness can be carried out without negative impact on the amount of ear yield as the correlation between yield and flowering date was positive and not significant. Furthermore, selection of for genotypes with high grains filling rate can improve ear yield while maintaining early maturity trait.

Table 7: Simple correlation coefficient between maize ear yield plant ${ }^{-1}$ and all studied earliness traits under low and high nitrogen conditions.

\begin{tabular}{|l|c|c|}
\hline \multirow{2}{*}{ Traits } & \multicolumn{2}{|c|}{ Ear yield plant-1 } \\
\cline { 2 - 3 } & Low N & High N \\
\hline Anthesis date, days & 0.10 & 0.25 \\
\hline Silking date, days & 0.06 & 0.29 \\
\hline Anthesis-Silking Interval (ASI), days & -0.29 & $0.57^{\star}$ \\
\hline Maturity date, days & 0.19 & $0.45^{\star}$ \\
\hline Grains filling period, days & $0.36^{*}$ & $0.39^{*}$ \\
\hline Grains filling rate, g/day & $0.97^{\star *}$ & $0.98^{\star *}$ \\
\hline The fraction of incident solar & 0.29 & $0.56^{\star}$ \\
\hline radiation absorbed $\left(I_{A}\right)$ & & \\
\hline
\end{tabular}

\section{DISCUSSION}

Productions of high yielding maize hybrids with improved capabilities of achieving physiological maturity during the average length of local growth season is critical for various agricultural systems worldwide. As a result, extensive breeding efforts for production of early maturing and high yielding maize cultivars have been reported by (Troyer, 1986; Lopes et al., 1995; Has et al., 2012 and Ngugi et al., 2013). These hybrids will have the ability to scape unexpected biotic and abiotic stresses that can happen at the end of maize growing season such as pathogen infestation and late drought, as well as weather changes such as decreased temperature of approaching winter (Revilla et al., 1999; Gasura et al., 2013 and Oyekunle et al., 2015). Crop physiological maturity depends on various plant related factors such as the genetic constitution and the physiological status of the plant. In addition, many environmental conditions such as light and photoperiod, temperature, and the soil nutritive minerals are also affecting this important trait. The flowering and its physiological consequences are critical traits for grains yield as they play major roles in controlling resource demands and remobilization from source-to-sink tissues (Dong et al., 2012). Consequently, intensive research has been carried out to uncover the underlying genetic and physiological mechanisms; however, these mechanisms are not completely understood. Dissection of these traits and understanding their controlling mechanisms will improve selection programs for earliness and early vigor and consequently agricultural practices and maize grains yield.

Recently, we have developed a set of thirteen new hybrids that exhibited significant differences in heterotic estimates over commercial hybrids in yield and yield related physiological traits (Abdel-Moneam and 
Ibraheem, 2015). Half of the genetic makeup of each of these hybrids is derived from their common maternal inbred parent (B73), whereas the other half is contributed by various parental inbred lines belonging to different heterotic groups. In the current investigation, we evaluated the impact of the different genetic makeup of these hybrids on their transition from vegetative to reproductive phase during the hybrid's life cycle as well as on the physiological maturity of these hybrids. We tested that via investigation of a set of earliness flowering and physiological maturity related traits and testing possible correlations between these traits and maize ear yield under $\mathrm{N}$ stress and $\mathrm{N}$ sufficient conditions.

The results revealed that the tested hybrids exhibit significant differences in flowering related traits including anthesis, silking and anthesissilking intervals (Tables 2\&3). Based on the phenotypes of their earliness traits (days from sowing to $50 \%$ flowering) and the general mean value of this trait (60.68 days for flowering), the tested hybrids can be relatively categorized into three subgroups. These subgroups include early flowering (with number of days from $\leq 50$ to 55 day, e.g. B73X PHG47, B73X HP301, B73X PH207, B73X PHj40, B73X NC358, B73X Mo17), intermediate flowering (hybrids with number of days from 55 to 65 day, e.g. B73X CML103, B73X Tzi8, B73X B97, B73X Rg5, B73X Inb209, B73X Sids63), and late flowering (with number of days from 65 to $\geq 70$ day, e.g. B73X Inb.204, and the check crosses SC3084, SC173, SC168, SC167, SC10) hybrids. Since these hybrids share a common female parent (the public maize inbred line B73, see material and methods and Abdel-Moneam and Ibraheem, 2015), the results thus suggest that the observed differences in flowering time and its related traits is due to the other individual genomes imported by various male parental inbred lines and the way these different genomes interact with B73 genome. It has been reported that the flowering of maize is complex quantitative trait with a number of small-effect QTLs (Buckler et al., 2009). In cereals, many flowering related genes act independently from or in coordination with environmental cues. For example, the earliness per se loci are potential genetic factors that control flowering time in cereals independently from the surrounding environment (Cockram et al., 2007). Therefore, in the current study, the output of the interaction between maize orthologous loci as well as other unknown flowering time related genes in parental genomes of each hybrid may be responsible for its flowering phenotypes (early, moderate or late). The nature of such interaction can be dominance, overdominance, or epistatic (Schnable and Swanson-Wagner, 2009). This hypothesis is supported by Troyer (1994) and Troyer (2001) who reported that the heterosis at flowering time related loci can have about $10 \%$ effect of flowering time.

The observed differences in the flowering time of the tested hybrids may be also due to their differential response to environmental conditions such light which plays significant role in controlling flowering time in plants. It has been reported that early flowering is associated with reduced response to 
light in many maize genotypes (Markelz et al., 2003). Interestingly, reduction in the activity of certain phytochromes (phyB), the primary photoreceptors in plants induced early flowering (Sheehan et al., 2004 and Sheehan et al., 2007). In addition, inactivation of a phytochromobilin synthase, encoded by gene $\mathrm{ZmHY}$, hindered the synthesis of the phytochrome chromophore and exhibited early flowering (Sawers et al., 2002 and Sawers et al., 2004). Therefore, the significant differences in the flowering times among the tested hybrids might suggest differences in their capacities in light perception and transduction. Therefore, it is possible that the early flowering hybrids (B73X Phg47, B73X HP301, B73X PH207 and B73X PHj40) might have relatively lower efficiencies in light perception than the relatively late flowering hybrids like (SC10, SC167, SC168 and SC 173). To test this hypothesis, we calculated and compared the fraction of incident solar radiation absorbed $\left(I_{A}\right)$ by the tested hybrids according to Tollenaar et al., (2004). Interestingly, the results indicated that the early flowering hybrids, B73X Phg47, B73X HP301, B73X PH207 and B73X PHj40 tended to have relatively lower $I_{A}$ values compared to late flowering hybrids (SC10, SC167, SC168 and SC 173). These results support an inductive role of reduction of light perception on early flowering in maize. In addition, the results revealed positive and moderate correlation between $I_{A}$ and anthesis date $\left(r=0.55^{*}\right.$, low $\mathrm{N}$ and $\mathrm{r}=$ $0.62^{*}$, high $\left.\mathrm{N}\right)$, silking date $\left(r=0.57^{*}\right.$, low $\mathrm{N} ; \mathrm{r}=0.65^{*}$ (high $\left.\mathrm{N}\right)$, and maturity date $\left(r=0.55^{\star}\right.$, low $\mathrm{N}, r=0.67^{\star *}$, high $\left.\mathrm{N}\right)$, as shown in Table 8. However, such finding needs more detailed comparative studies to figure out the underlying mechanisms of the reported differences and other contributing factors. In addition, another endogenous physiological cues such as nutritional status of the plant, sucrose, transitory starch, $\mathrm{C} / \mathrm{N}$ ratio in phloem, gibberellic acids, have been reported to contribute to regulation of flowering time in maize and other model systems (Rideout et al., 1992; Corbesier et al., 2002; Corbesier and Coupland, 2005 and Coneva, 2012).

Table, 8 : Simple correlation coefficient between the fraction of incident solar radiation absorbed $\left(I_{A}\right)$ and all studied earliness traits under low and high nitrogen conditions.

\begin{tabular}{|l|c|c|}
\hline \multirow{2}{*}{ Trait } & \multicolumn{2}{|c|}{$\begin{array}{c}\text { The fraction of incident solar radiation } \\
\text { absorbed }\left(\boldsymbol{I}_{\boldsymbol{A}}\right)\end{array}$} \\
\cline { 2 - 3 } & Low N & High N \\
\hline Anthesis date, day & $0.55^{\star}$ & $0.62^{*}$ \\
\hline Silking date, day & $0.57^{*}$ & $0.65^{\star}$ \\
\hline Anthesis-Silking Interval (ASI), day & 0.24 & $0.45^{\star}$ \\
\hline Maturity date, day & $0.55^{\star}$ & $0.67^{\star *}$ \\
\hline Grains filling period, day & -0.13 & -0.07 \\
\hline Grains filling rate, g/day & $0.35^{*}$ & $0.58^{*}$ \\
\hline Ear yield plant & & $0.56^{*}$ \\
\hline
\end{tabular}

Similar to early flowering related traits, the results revealed significant differences among the tested hybrids in earliness-related critical physiological traits such as grains filling period, grains filling rate, and physiological maturity under both $\mathrm{N}$ stress and $\mathrm{N}$ sufficient conditions. The magnitude of 
grains filling rate usually drives both grains filling period and physiological maturity. As a result, rapid grains filling has been very crucial physiological indicator on not only the early physiological maturity but also on the physiological status of the whole plant after pollination. Based on the values of individual and general mean grains filling rates, the tested hybrids can be roughly classified into three subgroups: slow rate grains filler $(\leq 1.4$ to 3.5 g/day, e.g. B73X HP301, B73X PHj40 and B73X PH207), intermediate rate grains filler (3.5 to $4.5 \mathrm{~g} /$ day, e.g. B73X Phg47, B73X B97, B73X Mo17, B73X Inb209, B73X Sids63, B73X Rg5, B73X Inb.204, SC3084, SC168, SC167, $\mathrm{SC} 173, \mathrm{SC} 10)$ and rapid rate grains filler $(4.5$ to $\geq 6 \mathrm{gram} /$ day, e.g. B73X CML103, B73X TZI8 and B73X NC358) under N stress conditions. The classification of the tested hybrids was slightly changed under $\mathrm{N}$ sufficient conditions because of the high $\mathrm{N}$ induced changes in grains filling rates (Table 4). Similar differences in grains filling rate among maize genotypes has been reported (Wang et al., 1999; Gambin et al., 2007; Lee and Tollenaar, 2007; Borras et al., 2009 and Magorokosho et al., 2009). In addition, the correlation analysis indicated strong positive correlation between ear yield plant ${ }^{-1}$ and grains filling rate under low $\left(r=0.98^{\star *}\right)$ and high $(r=$ $\left.0.97^{\star \star}\right) \mathrm{N}$ rates (Table 7 ). These results agree with those reported by Gasura et al., (2013). In maize, high grains filling rate is driven mainly by the capacity of maize sink tissues after pollination which is influenced by the efficiency of early kernel set, pollination efficiency and ASI (Bolanos and Edmeades, 1993a\&b and Carvoca and Otegui, 2007). Generally, the significant differences in grains filling rate among the tested hybrids reflect significant differential heterotic effects on grains filling rate related genetic loci. These results also suggest that the tested hybrids employ different adaptive physiological strategies for management of their resources during grains filling period. Since grains filling rate describes the efficiency of plant to remobilize their metabolic resources into the developing kernels, thus, the observed differences in grains filling rate among the tested hybrids suggest differential capacities of these hybrids to remobilize their photoassimilates from active photosynthesizing leaves to the developing kernels. Interestingly, the cross B73X CML103 maintained the highest values of grains filling rate ( $6.87 \mathrm{~g} /$ day, low N, $6.05 \mathrm{~g} /$ day, high $\mathrm{N})$, and significantly surpassed over all tested hybrids including the check crosses under both $\mathrm{N}$ rates. This new hybrid also has moderate length of grains filling period (44.33 day). These results reveal vigorous and sustainable resource remobilization from sourceto-sink tissues in this promising hybrid. Interestingly, the B73X CML103 also had the highest ear yield (Table 5) which seems to be the driving force behind the observed vigorous and sustainable resource remobilization in this hybrid after pollination. Further, this hybrid exhibited the shortest ASI interval (3.67 days) which protect it from any possible pollination stress and reduction in kernel number. Therefore, the results indicate that the B73X CML103 has high ear yield with acceptable package of other physiological traits and 
consequently this study recommend this hybrid for large scale production and commercial testing.

In addition to the significant differences induced by diverse genetic constitution of the tested hybrids, high nitrogen treatment also stimulated significant changes, as compared to low $\mathrm{N}$ rate, in most of the tested earliness related traits. For instance, the results indicated that high $\mathrm{N}$ treatment significantly increased the number of days needed for anthesis, accelerated reaching physiological maturity, extended the length of the grains filing period and improved ear yield plant ${ }^{-1}$ for most tested hybrids. These findings indicate simulative effect of high $\mathrm{N}$ treatment on the earliness of the tested hybrids. On the other hand, high $\mathrm{N}$ treatment reduced number of days required for silk emergence and ASI. Interestingly high $\mathrm{N}$ treatment also induced some interesting fluctuations in grains filling rate among hybrids. For example, it increased the rate of grains filling in nine hybrids namely B73X PHj40, B73X HP301, B73X Mo17, B73X Inb209, B73X Sids63, B73X Inb.204, SC168, SC167 and SC10) as compared to N limited conditions with B73X Sids63 being the highest responsive hybrid. However, high N fertilization also reduced the grains filling rate of seven hybrids including B73X B97, B73X CML103, B73X TZI8, B73X NC358, B73X Rg5, SC3084 and SC173 compared to low N rate with B73X CML103 being superior to the rest of hybrids in this group. These results suggest that high $\mathrm{N}$ rate may (1) retard the transition of SAM from vegetative mode to reproductive mode, (2) delay the senescence of maize leaves and thus increase the duration of photoassimilates' synthesis which consequently increases the strength of the source tissues, (3) minimize the number of aborted kernels and thus increase the capacity of the sink tissues and (4) protect the photoreceptor and thus increase efficiency of light perception which is negatively associate with early flowering.

\section{CONCLUSION}

The new hybrids differ significantly in flowering related traits such as anthesis, silking, anthesis-silking intervals (ASI), and the efficiency of light absorption of plant cover under $\mathrm{N}$ stress and $\mathrm{N}$ sufficient conditions. They also differ significantly in physiological maturity related traits such as grains filling period, and grains filling rate. Such differences are driven by the significant differences in the genetic constitution of the new hybrids. The ear yield of the new hybrids is strongly and positively correlated with grains filling rate under low $\left(r=0.97^{\star \star}\right)$ and high $\left(r=0.98^{\star *}\right) \mathrm{N}$ rates. Interestingly, among hybrids, the cross B73X CML103 maintained the highest ear yield with acceptable package of other flowering and physiological traits. It attained the highest values of grains filling rate $(6.87 \mathrm{~g} /$ day, low $\mathrm{N}, 6.05 \mathrm{~g} /$ day, high $\mathrm{N})$, moderate length of grains filling period (44.33 days), the shortest ASI (3.67 days) which makes it less vulnerable to any possible pollination stress and thus minimizes its negative consequences on grains yield. Therefore, we recommend this hybrid for large scale production and commercial testing. In addition, the new hybrids provide unique plant material for downstream 
molecular biology experiments to uncover molecular mechanisms underlying the differential flowering and grains filling phenotypes.

Acknowledgement: This work was supported by a Mansoura University's award to Dr. F. I. Ibraheem.

\section{REFERENCES}

Abdel-Monaem, M. A., (2000). Breeding studies on maize tolerance to low nitrogen fertilization. M.Sc. Thesis Agric. Sci. (Agronomy), Faculty of Agric. Mansoura University.

Abdel-Moneam, M.A. and F. Ibraheem (2015). Heterosis of new maize hybrids in yield, yield components, physiological traits and some genetic parameters under low and high nitrogen conditions. J. of Crop Science, 6 (1):131-141.

Akintoye, H. A.; J. G. Kling and E. O. Lucase (1999). N-use efficiency of single, double and synthetic maize lines grown at four $\mathrm{N}$ levels in three ecological zones of West Africa. Field Crops Res., 60 (3): 189-199 .

Banziger, M.; P.S. Setimela; D. Hodson and B. Vivek (2004). Breeding for improved drought tolerance in maize adapted to southern Africa. In: New directions for a diverse planet: Proceedings of the 4th nternational Crop Science Congress, Brisbane, Australia. 26 Sept.-1 Oct. 2004. The Regional Institute Ltd., Gosford, NSW, Australia.

Bello, O.B.; S.Y. Abdulmaliq; M.S. Afolabi and S.A. Ige (2010). Correlation and path coefficient analysis of yield and agronomic characters among open pollinated maize varieties and their $\mathrm{F} 1$ hybrids in a diallel cross. Afri. J. Biotech., 9 (18): 2633-2639

Bello, O. B.; S. Y. Abdulmaliq; S. A. Ige; J. Mahamood; F. Oluleye; M. A. Azeez and M. S. Afolabi (2012). Evaluation of early and late/intermediate maize varieties for grains yield potential and adaptation to a Southern Guinea Savanna Agro-ecology of Nigeria. International J. of Plant Res., 2(2): 14-21

Bolanos, J. and G. O. Edmeades (1993a). Eight cycles of selection for drought tolerance in low land tropical maize. I. Responses in yield, biomass and radiation utilization. Field Crop Res., $31: 233-252$.

Bolanos, J., and G.O. Edmeades (1993b). Eight cycles of selection for drought tolerance in tropical maize. II. Responses in reproductive behavior. Field Crops Res. 31:253-268 .

Borras, L.; C. Zinselmeier; M.L. Senior; M.E. Westgate and M.G. Muszynski (2009). Characterization of grains filling patterns in diverse maize germplasm. Crop Sci., 49:999-1009. 
Buckler, E.S; J.B. Holland; P.J. Bradbury; C.B. Acharya; P.J. Brown; C. Browne; E. Ersoz; S. Flint-Garcia; A. Garcia; J.C. Glaubitz; M.M. Goodman; C. Harjes; K. Guill; D.E. Kroon; S. Larsson; N.K. Lepak; H. Li; S.,E. Mitchell; G. Pressoir; J.A. Peiffer; M.O. Rosas; T.R. Rocheford; M.C. Romay; S. Romero; S. Salvo; H. Sanchez Villeda; H.S Silva; Q. Sun; F. Tian; N. Upadyayula; D. Ware; H. Yates; J. Yu; Z. Zhang; S. Kresovich and M.D. McMullen (2009). The genetic architecture of maize flowering time. Science. 2009 Aug 7;325(5941):714-8, (C.F. Computer Search).

Carvoca, J. and M.E. Otegui (2007). Ovary growth and maize kernel set. Crop Sci., 47:1104-1110.

Cockram, J.; H. Jones; F.J. Leigh; D. O'Sullivan; W. Powell; D.A. Laurie and A.J. Greenland (2007). Control of flowering time in temperate cereals: genes, domestication, and sustainable productivity. J. of Experimental Botany, 58: 1231-1244

Colasanti, J. and M. Muszynski (2009). The Maize Floral Transition. In Handbook of Maize: Its Biology, J.L. Bennetzen and S.C. Hake (eds.), 41-54, Springer Science + Business Media, LLC 2009, DOI: 10.1007/978-0-387-79418-1_23C ,

Coneva, V. (2012). Transcript and metabolite signature of the late-flowering maize mutant indeterminate1: implications for the floral transition in day-neutral species, Ph.D. Thesis, the University of Guelph, Guelph, Ontario, Canada, (C.F. Computer Search).

Corbesier, L; G. Bernier and C. Perilleux (2002) C : N ratio increases in the phloem sap during floral transition of the long-day plants Sinapis alba and Arabidopsis thaliana. Plant and Cell Physiology, 43: 684-688.

Corbesier, L. and G. Coupland (2005) Photoperiodic flowering of Arabidopsis: integrating genetic and physiological approaches to characterization of the floral stimulus. Plant Cell and Environment 28: 54-66.

Derera, J.; P. Tongoona; B.S. Vivek and M.D. Laing (2007). Gene action controlling grains yield and secondary traits in southern African maize hybrids under drought and non-drought environments. Euphytica, 162:411-422.

Diallo, A. O.; A. Adam; R. K. Akanvou and P. Y. K. Sallah (1996). Response of S4 maize lines evaluated under stress and nonstress environments. Proc. Of a Sym., CIMMYT, El Batan, Mexico, 25-29 March 1996, Part (1) 280-286.

Dong, Z.; O. Danilevskaya; T. Abadie; C. Messina and N. Coles (2012). A Gene Regulatory Network Model for Floral Transition of the Shoot Apex in Maize and Its Dynamic Modeling. PLoS ONE 7(8): e43450. doi:10.1371/journal.pone.0043450, (C.F. Computer Search).

Dwyer, L.M.; B.L. Ma; L. Evenson and R.L. Hamilton (1994). Maize physiological traits related to grains yield and harvest moisture in midto short-season environments. Crop Sci., 34:985-992 .

El-Badawy, M. E. M. (2013). Heterosis and combining ability in maize using diallel crosses among seven new inbred lines. Asian J. of Crop Sci., 5 (1) : 1-13. 
Gambin, B.L.; L. Borras and M.E. Otegui (2007). Kernel water relations and duration of grains filling in maize temperate hybrids. Field Crops Res., 101:1-9.

Gasura, E.; P. Setimela; R. Edema; P.T. Gibson; P. Okori and A. Tarekegne (2013). Exploiting grains-filling rate and effective grains-filling duration to improve grains yield of early-maturing maize. Crop Sci., 53:1-9.

Has, I.; V. Has; A. Copandean; T. Schiop and C. Rotar (2012). Evaluation of maize "turda" germplasm as sources of earliness in breeding programs. Bulletin UASVM Agriculture 69(1): 103-113.

Jung, C. and A. Muller (2009). Flowering time control and applications in plant breeding. Trends in Plant Sci., 14: 563-573.

Lavergne, V.; M. Lefort-Buson; J. J. Daudin; A. Charcosset; J. P. Sampoux and A. Gallais (1991). Genetic variability among populations of maize germplasm 1. Comparative analysis of top cross values and per se values of populations. Maydica, 36: 227-236.

Lee, E.A. and M. Tollenaar (2007). Physiological basis of successful breeding strategies for maize grains yield. Crop Sci., 47:202-215.

Lopes, U.V.; J.D. Galvao and C.D. Cruz (1995). Inheritance of the flowering time in maize: Diallel analysis. Pesq. Agropec. Bras., Brasilia, 30 (10): 1267-1271.

Magorokosho, C.; B. Vivek and J. MacRobert (2009). Characterization of maize germplasm grown in Eastern and Southern Africa: Results of the 2008 regional trials coordinated by CIMMYT. CIMMYT, Harare, Zimbabwe. (C.F. Computer Search).

Markelz, N.; D. Costich and T. Brutnell (2003). Photomorphogenic responses in maize seedling development. Plant Physiology, 133: 1578-1591.

McSteen P.; D. Laudencia-Chingcuanco and J. Colasanti (2000). A floret by any other name: control of meristem identity in maize. Trends in Plant Sci., 5: 61-66.

Ngugi, K.; J.O. Collins and S. Muchria (2013). Combining, earliness, short anthesis to silking intervals and yield based selection indices under intermittent water stress to select for drought tolerant maize. Australian J. of Crop Sci., 7(13):2014-2020.

Oyekunlea, M.; B. Badu-Aprakua; S. Hearnea and J. Francoa (2015) Genetic diversity of tropical early-maturing maize inbreds and their performance in hybrid combinations under drought and optimum growing conditions. Field Crops Res., (170): 55-65.

Pingali, P.L. and S. Pandey (2001). Meeting world maize needs: Technological Opportunities for the Public Sector. In: PR Pingali, Editor, CIMMYT, 1999-2000, World Maize Facts and Trend, CIMMYT, Mexico, D.F. Mexico, P, 1-24.

Potheing, R.S. (1990). Phase change and the regulation of shoot morphogenesis in plants. Science, 250: 923-930. 
Randjelovic, V.; S. Prodanovic; Z. Tomic and A. Simic (2011). Genotype x year effect on grains yield and nutritive values of maize (Zea mays L.). J. Anim., Vet. Sci. Adv., 10(7): 835-840.

Raun, W. R. and G. V. Johnson (1999). Improving nitrogen use efficiency for cereal production. Agron. J., $91:$ 357-363.

Revilla, P.; R. A. Malvar; M. E. Cartea; A. Butrón and A. Ordás (1999). Inheritance of cold tolerance at emergence and during early season growth in maize. Crop Sci., 40 (6): 1579-1585.

Rideout, J.W.; C.D.J. Raper and G.S. Miner (1992). Changes in ratio of soluble sugars and free amino nitrogen in the apical meristem during floral transition in tobacco. International J. of Plant Sci., 153: 78-88

Ritchie, S.W.; J.J. Hanway and G.O. Benson (1997). How a corn plant develops. Spec. Rep. No. 48. lowa State University of Science and Technology Cooperate Extension Service, Ames, IA.

Saeid, H.; R. Seyedsharifi; Sh. Jamaati-e-Somarin; M. Hassanzadeh; M. Shiri-e-Janagard and R. Zabihi-e-Mahmoodabad (2010). Evaluation of plant density and nitrogen fertilizer on yield components and growth of maize. World Applied Sci. J., 8 (9): 1157-1162

Salih, A.I.S.; A.A. Abdelmula; E.M.A. Bashir; S. U. Baloch; S. K. Baloch and W. Bashir (2014). Genetic variation of flowering trait in maize (Zea mays L.) under drought stress at vegetative and reproductive stages. J. of Biology, Agriculture and Healthcare, 4 (20): 108-113

Sallah, P. Y. K.; N. J. Ehlke and J. L. Geadelmann (1996). Selection for response to low nitrogen in the la posta maize population. Proc. of a Symposium, CIMMYT , El Batan, Mexico, 25-29 March, 1996, Part (3): 502-507.

Sawers, R.J.H.; P.J. Linley; P.R. Farmer; N.P. Hanley and D.E. Costich (2002). Elongated mesocotyl1, a phytochrome-deficient mutant of maize. Plant Physiology, 130: 155-163.

Sawers, R.J.H.; P.J. Linley; J.F. Gutierrez-marcos; T. Delli-bovi and P.R. Farmer (2004) The Elm1 (ZmHy2) gene of maize encodes a phytochromobilin synthase. Plant Physiology, 136: 2771-2781.

Schnable, P.S. and R.S. Swanson-Wagner (2009). Heterosis. In Handbook of Maize: Its Biology, J.L. Bennetzen and S.C. Hake (eds.), 457-467, Springer Science + Business Media, LLC 2009, DOI: 10.1007/978-0387-79418-123 @ .

Schnell, F. W. and C. Schmidt (1975). The association of earliness with yield during generative development of maize hybrids. Cereal Research Communications, 3 (3): 215-225.

Shaw, R.H. and H.C.S. Thom (1951a). On the phenology of field corn, the vegetative period. Agronomy J., 43: 9-15

Shaw, R.H. and H.C.S. Thom (1951b). On the phenology of field corn, silking to maturity. Agronomy J., 43: 541-546.

Sheehan, M.; L. Kennedy; D. Costich and T. Brutnell (2007). Subfunctionalization of PhyB1 and PhyB2 in the control of seedling and mature plant traits in maize. The Plant J., 49: 338-353. 
Sheehan, M.; P. Farmer and T. Brutnell (2004). Structure and expression of maize phytochrome family homeologs. Genetics, 167: 1395-1405.

Simpson, G. and C. Dean (2002). Arabidopsis, the Rosetta stone of flowering time? Science, 296: 285-289.

Sultan, M.S.; M.A. Abdel-Moneam; S.M.G. Salama and A.M. El-Oraby (2013). Combining ability and heterosis for some flowering and vegetative traits of five maize inbreds under two nitrogen levels fertilization. J. Plant Production, Mansoura Univ., 4 (3):485-495.

Tollenaar, M.; A. Ahmadzadeh, and E.A. Lee (2004). Physiological basis of heterosis for grains yield in maize. Crop Sci., 44: 2086-2094

Troyer, A.F. (1986). Selection for early flowering in corn: 18 adapted F2 populations. Crop Sci., 26: 283-285.

Troyer, A. F. (1994). Breeding early corn. In: Specialty corns, Edited by A.R. Hallauer, C.R.C. Press: 341-396.

Troyer, A. F. (2001). Temperate corn background, behavior and breeding, CRC Press Boca Raton, London, New York, Washington DC.

Wang, G.; M.S. Kang and O. Moreno (1999). Genetic analyses of grains filling rate and duration in maize. Field Crops Res., 61:211-222.

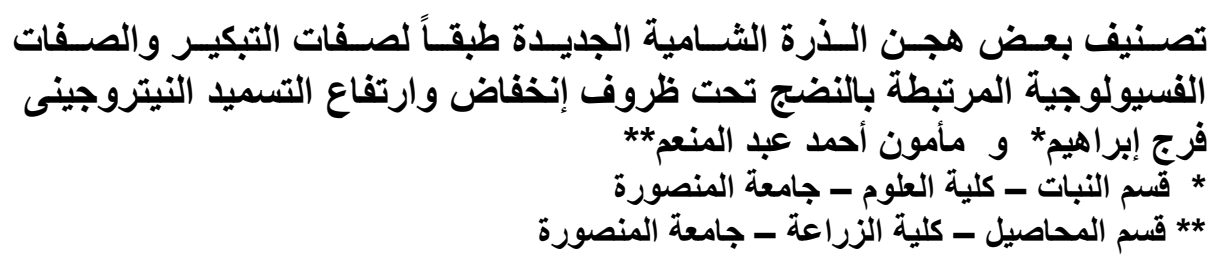

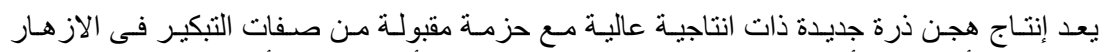

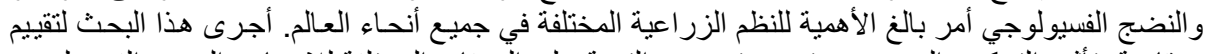

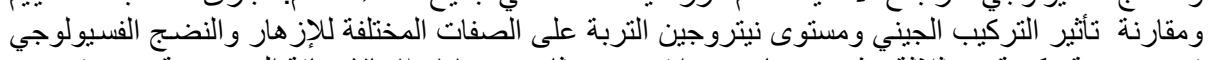

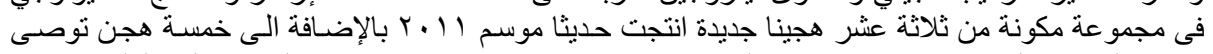

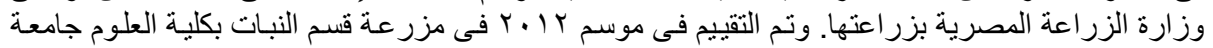

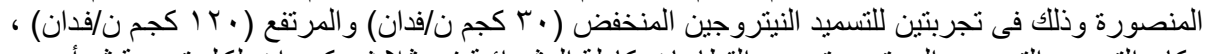

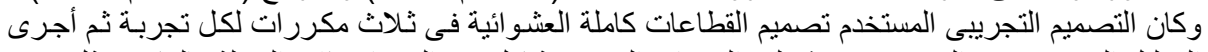

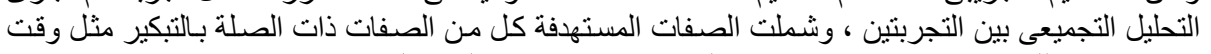

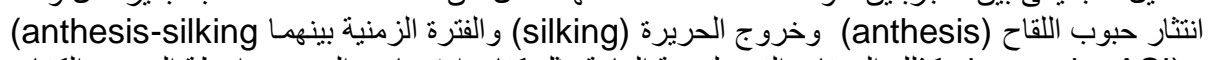
intervals, ASI)

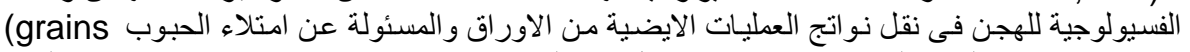

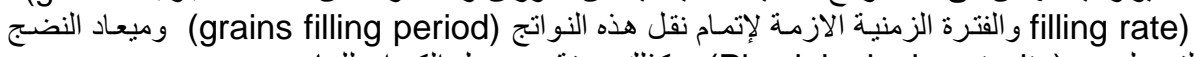

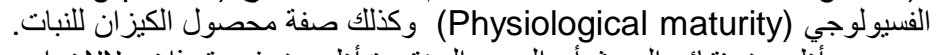

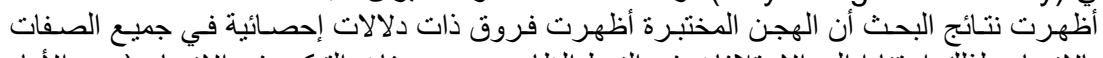

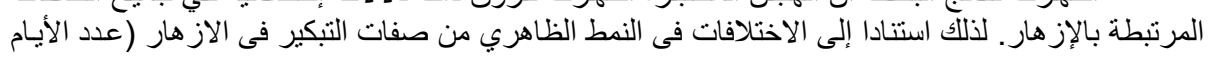

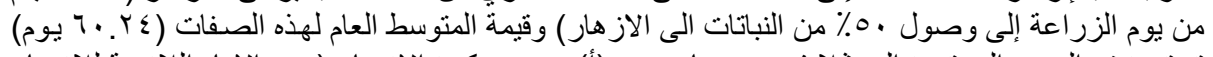

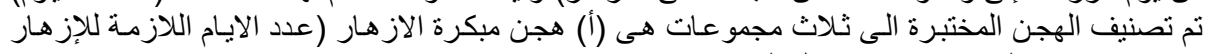

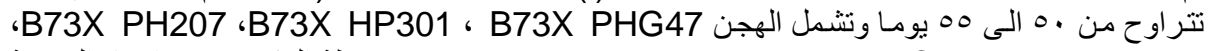

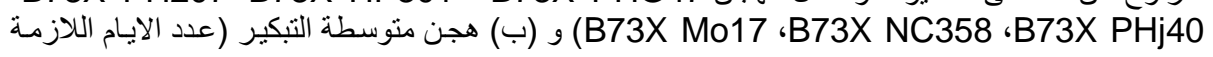




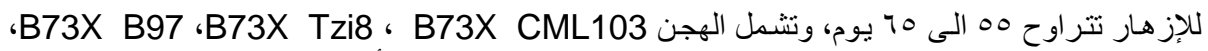

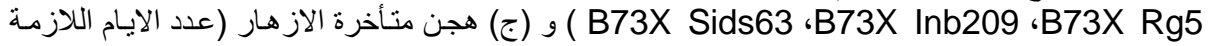

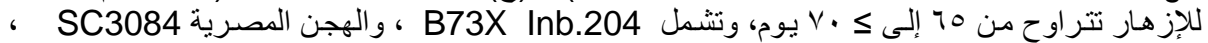

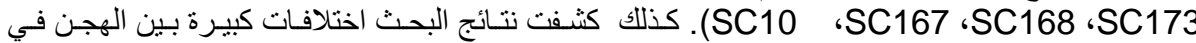

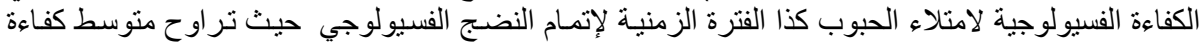

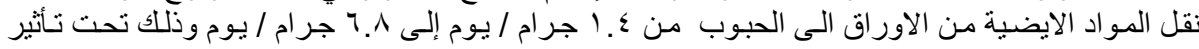

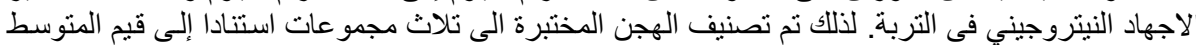

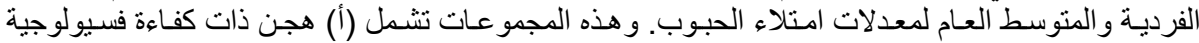

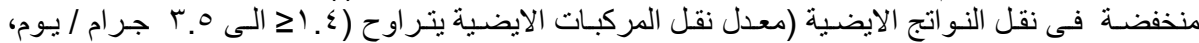
وتثمل B73X HP301, B73X PHj40, B73X PH207 و(ب) هجن ذات كفاءة فسيولوجية منتوسطة

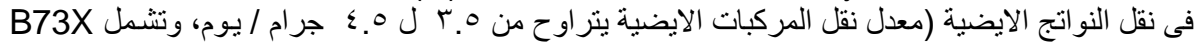

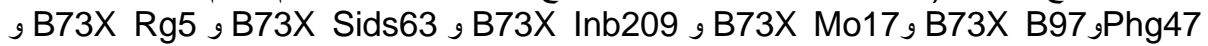

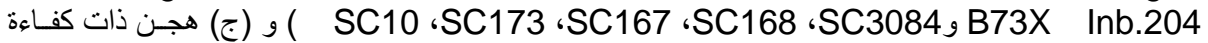

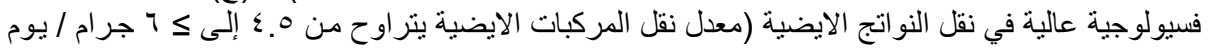

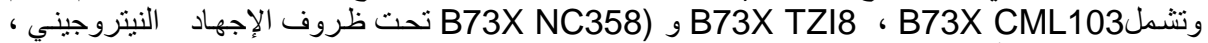

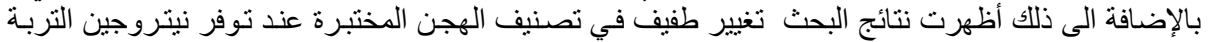

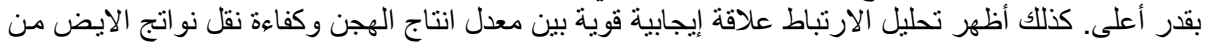

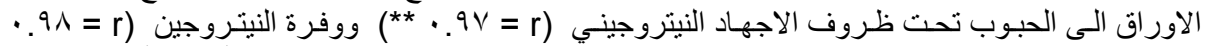

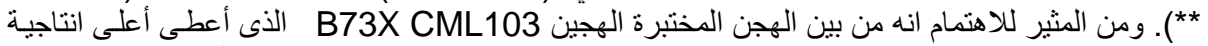

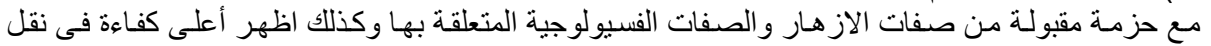

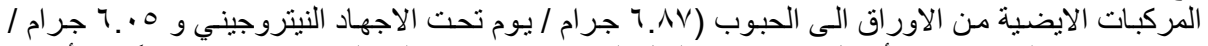

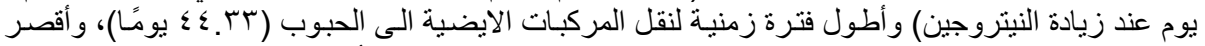

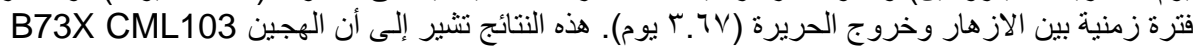

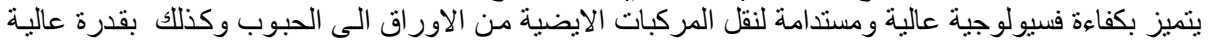

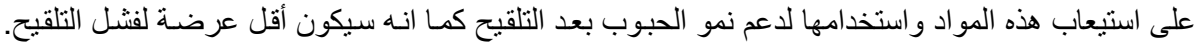

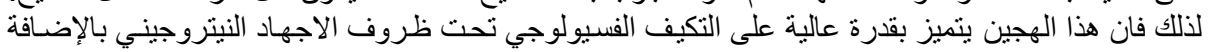

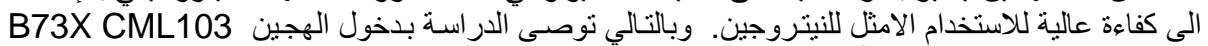
فى تجارب التقييم الأوسع تمهيداً لإنتاجه على نطاق تجارى. 